\title{
Diversity and abundance of conspicuous macrocrustaceans on coral reefs differing in level of degradation
}

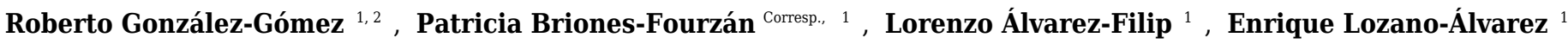 \\ ${ }^{1}$ Instituto de Ciencias del Mar y Limnología, Unidad Académica de Sistemas Arrecifales, Universidad Nacional Autónoma de México, Puerto Morelos, \\ Quintana Roo, Mexico \\ 2 Posgrado en Ciencias del Mar y Limnología, Universidad Nacional Autónoma de México, Mexico, Ciudad de México, Mexico \\ Corresponding Author: Patricia Briones-Fourzán \\ Email address: briones@cmarl.unam.mx
}

Coral reefs sustain abundant and diverse macrocrustaceans that perform multiple ecological roles, but coral reefs are undergoing massive degradation that may be driving changes in the species composition and abundance of reef-associated macrocrustaceans. To provide insight into this issue, we used non-destructive visual census techniques to compare the diversity and abundance of conspicuous macrocrustaceans (i.e., those $>1 \mathrm{~cm}$ and visible without disturbance) between two shallow Caribbean coral reefs similar in size ( 1.5 km in length) and close to each other, but one ("Limones") characterized by extensive stands of the branching coral Acropora palmata, and the other ("Bonanza") dominated by macroalgae and relic coral skeletons and rubble (i.e., degraded). We also assessed the structural complexity of each reef and the percent cover of various benthic community components. Given the type of growth of $A$. palmata, we expected to find a greater structural complexity, a higher cover of live coral, and a lower cover of macroalgae on Limones, and hence a more diverse and abundant macrocrustacean community on this reef compared with Bonanza. Overall, we identified 63 macrocrustacean species (61 Decapoda and two Stomatopoda). Contrary to our expectations, structural complexity did not differ significantly between the back-reef zones of these reefs but varied more broadly on Limones, and the diversity and abundance of macrocrustaceans were higher on Bonanza than on Limones despite live coral cover being higher on Limones and macroalgal cover on Bonanza. However, the use of various types of microhabitats by macrocrustaceans differed substantially between reefs. On both reefs, the dominant species were the clinging crab Mithraculus coryphe and the hermit crab Calcinus tibicen, but the former was more abundant on Bonanza and the latter on Limones. M. coryphe occupied a diverse array of microhabitats but mostly coral rubble and relic skeletons, whereas $C$. tibicen was often, but not always, found associated with colonies of Millepora spp. A small commensal crab of $A$. palmata, Domecia acanthophora, was far more abundant on Limones, emerging as the main discriminant species between reefs. Our 
results suggest that local diversity and abundance of reef-associated macrocrustaceans are partially modulated by habitat degradation, the diversity of microhabitat types, and the establishment of different commensal associations rather than by structural complexity alone. 
1 Diversity and abundance of conspicuous macrocrustaceans on coral reefs differing in level

2 of degradation

3

4 Roberto González-Gómez ${ }^{1,2}$, Patricia Briones-Fourzán ${ }^{1 *}$, Lorenzo Álvarez-Filip ${ }^{1}$, Enrique

5 Lozano-Álvarez ${ }^{1}$

6

$7{ }^{1}$ Unidad Académica de Sistemas Arrecifales, Instituto de Ciencias del Mar y Limnología, 8 Universidad Nacional Autónoma de México.

9

2Posgrado en Ciencias del Mar y Limnología, Universidad Nacional Autónoma de México, 11 Ciudad Universitaria, Ciudad de México, México.

12

13

14 *Corresponding author: Patricia Briones-Fourzán.

15 e-mail: briones@cmarl.unam.mx 


\section{ABSTRACT}

Coral reefs sustain abundant and diverse macrocrustaceans that perform multiple ecological roles, but coral reefs are undergoing massive degradation that may be driving changes in the species composition and abundance of reef-associated macrocrustaceans. To provide insight into this issue, we used non-destructive visual census techniques to compare the diversity and abundance of conspicuous macrocrustaceans (i.e., those $>1 \mathrm{~cm}$ and visible without disturbance) between two shallow Caribbean coral reefs similar in size $(\sim 1.5 \mathrm{~km}$ in length) and close to each other, but one ("Limones") characterized by extensive stands of the branching coral Acropora palmata, and the other ("Bonanza") dominated by macroalgae and relic coral skeletons and rubble (i.e., degraded). We also assessed the structural complexity of each reef and the percent cover of various benthic community components. Given the type of growth of A. palmata, we expected to find a greater structural complexity, a higher cover of live coral, and a lower cover of macroalgae on Limones, and hence a more diverse and abundant macrocrustacean community on this reef compared with Bonanza. Overall, we identified 63 macrocrustacean species (61 Decapoda and two Stomatopoda). Contrary to our expectations, structural complexity did not differ significantly between the back-reef zones of these reefs but varied more broadly on Limones, and the diversity and abundance of macrocrustaceans were higher on Bonanza than on Limones despite live coral cover being higher on Limones and macroalgal cover on Bonanza. However, the use of various types of microhabitats by macrocrustaceans differed substantially between reefs. On both reefs, the dominant species were the clinging crab Mithraculus coryphe and the hermit crab Calcinus tibicen, but the former was more abundant on Bonanza and the latter on Limones. $M$. coryphe occupied a diverse array of microhabitats but mostly coral rubble and relic skeletons, whereas $C$. tibicen was often, but not always, found associated with colonies of Millepora spp. A small commensal crab of A. palmata, Domecia acanthophora, was far more abundant on Limones, emerging as the main discriminant species between reefs. Our results suggest that local diversity and abundance of reef-associated macrocrustaceans are partially modulated by habitat degradation, the diversity of microhabitat types, and the establishment of different commensal associations rather than by structural complexity alone. 


\section{INTRODUCTION}

Habitat complexity is an important factor driving the abundance and diversity of associated species by facilitating niche separation and resource partitioning (Vytopil \& Willis, 2001; Idjadi \& Edmunds, 2006). Keystone structures (sensu Tews et al., 2004) are distinct spatial structures that create complex habitats that facilitate species' coexistence by offering food resources and shelter against predators and various environmental stressors (Bruno \& Bertness, 2001; Kerry \& Bellwood, 2015). In coral reefs, keystone structures are created by scleractinian corals, which provide great spatial complexity to the system and multiple shelters for other organisms in the form of crevices, holes, and branches.

The role of corals in maintaining abundant and diverse communities of reef invertebrates is well recognized. For example, Stella et al. (2011) identified 869 coral-associated invertebrate species, with arthropods (mostly crustaceans) as the major contributors to the overall diversity. Not only are reef macrocrustaceans (in particular Decapoda and Stomatopoda) highly diverse; they are also abundant and perform multiple ecological roles. They are part of numerous feeding guilds, acting as predators, parasites, herbivores, scavengers, and detritivores, as well as suspension and deposit feeders (Abele, 1976; Glynn \& Enochs, 2011; Stella et al., 2011), and constitute a critical link between primary production and a wide array of higher order consumers, including reef fishes (Randall, 1967). Some macrocrustaceans defend live coral from potential predators (McKeon \& Moore, 2014), maintain coral health by clearing sediments (Stewart et al., 2006), or eliminate parasites from reef fishes, many of which are of economic value (Becker \& Grutter, 2004). Therefore, macrocrustaceans are a key component of coral reef ecosystems, making it necessary to understand the potential effects that coral reef degradation may have on their communities.

Coral reefs are undergoing massive degradation due to the effects of multiple stressors, including climate change induced-bleaching, increases in disease outbreaks and prevalence, eutrophication, and invasive or destructive fishing practices (Hughes et al., 2017). This is particularly true for Caribbean coral reefs, where declines in reef architectural complexity and phase shifts from coral to macroalgal dominance have been extensively documented (Gardner et al., 2003; Álvarez-Filip et al., 2009; Bruno et al., 2014; Jackson et al., 2014; Suchley, McField \& Álvarez-Filip, 2016). Coral reef degradation is likely to have serious consequences for ecosystem functioning and services, as well as for reef biodiversity (Álvarez-Filip et al., 2009), and there is 
support for this latter assumption in the case of reef fishes (e.g. Graham et al., 2011; Coker, Wilson \& Pratchett, 2014; Álvarez-Filip et al., 2015; Newman et al., 2015). However, predictions for invertebrate taxa are less clear because different studies have reported contrasting results (see Graham \& Nash, 2013). For example, in Papua New Guinea, the density and abundance of several macroinvertebrate groups, including motile crustaceans, decreased in reefs with lower architectural complexity due to acidification compared with more complex reefs (Fabricius et al., 2014). In the US Virgin Islands, diversity, but not abundance, of invertebrates was positively related with topographic complexity, but not with coral diversity or live coral cover (Idjadi \& Edmunds, 2006). In contrast, invertebrate assemblages were more diverse and abundant on dead than on live coral habitats in Panama (Nelson, Kuempel \& Altieri, 2016), whereas habitat complexity accounted for very little of the variability in invertebrates (including arthropods) on Caribbean Orbicella reefs (Newman et al., 2015). These contrasting results suggest that many reef-associated invertebrates do not necessarily benefit from the presence of live corals per se, but from the complex 3-D framework of coral reefs, which can persist for years after the death of corals.

One of the most structurally complex, reef-building corals in the Caribbean region is the branching coral Acropora palmata. This species, once dominant in the region, form thick stands that provide an intricate network of crevices on shallow-water reefs $(<5 \mathrm{~m})$. The populations of this species have sustained extensive mortality since the early 1980s, substantially reducing coral cover, increasing substratum for algal growth, and drastically reducing reef complexity (Aronson \& Precht, 2001; Alvarez-Filip et al., 2009; Jackson et al., 2014). Currently, Acropora-dominated reefs are rare. For example, a recent assessment in 107 sites along the Mesoamerican Reef (MAR) revealed that $A$. palmata was present (mostly at low cover values) in only $20 \%$ of the sites, and that only one site ("Limones" reef), located in the northernmost Mexican portion of the MAR, exhibited extensive stands of $A$. palmata resulting in a high ( $>35 \%)$ cover of this branching coral (Rodríguez-Martínez et al., 2014). Therefore, assessing the composition and structure of the ecological condition on these Acropora-dominated reefs is crucial to elucidate how reef degradation is modifying the ecological relationships on coral reefs.

The aims of the present study were twofold: to obtain a list of species of conspicuous macrocrustaceans associated to shallow Caribbean reef habitats, and to compare the diversity and abundance of these macrocrustaceans between Limones reef and another reef ("Bonanza"), 
109 similar in size to Limones but highly degraded, to elucidate the potential effects of coral reef

110 degradation on this type of invertebrates. We predicted that the diversity and abundance of

111 macrocrustaceans would be higher in Limones because the presence of extensive stands of live

112 A. palmata would presumably confer a greater structural complexity and provide a broad

113 diversity of microhabitats potentially used by reef-associated species (Roberts \& Ormond, 1987;

114 Garpe et al., 2006).

115

116 MATERIALS AND METHODS

117 Study site

118 The study was conducted at the Puerto Morelos Reef National Park (PMRNP; Fig. 1A), a

119 marine protected area located on the NE coast of the Yucatan Peninsula, Mexico. The PMRNP is

120 an extended fringing reef system composed of a series of reef units that differ in size and

121 structural complexity (Lozano-Álvarez et al., 2017; Morillo-Velarde et al., 2018), separated from

122 the coast by a shallow $(<5 \mathrm{~m})$ reef lagoon. Along the reef tract, coral cover tends to be greater on

123 the back-reef and crest zones than on the low-relief fore-reef, which descends gradually into an

124 extensive sand platform at 20-25m (Jordán-Dahlgren, 1993). Two of these reef units are

125 Limones (centered at $20^{\circ} 59.1^{\prime} \mathrm{N}, 86^{\circ} 47.9^{\prime} \mathrm{W}$ ) and Bonanza (centered at $20^{\circ} 57.6^{\prime} \mathrm{N}, 86^{\circ} 48.9^{\prime} \mathrm{W}$ )

126 (Fig. 1A). Both reefs are similar in length $(\sim 1.5 \mathrm{~km})$, depth and distance from the coast, but

127 differ in their level of degradation, as indicated by several studies. Healthy and resilient

128 populations of Acropora palmata have been reported since 1985 on Limones (Rodriguez-

129 Martínez et al., 2014) (Fig. 1B), and recently Morillo-Velarde et al. (2018) found 50\% live coral

130 cover, mostly A. palmata, along the central part of Limones. In contrast, live coral cover on

131 Bonanza has gradually declined from 33\% in 1985 (Jordán-Dahlgren, 1993) to 12\% in 2006-

1322007 (Carriquiry et al., 2013) and 7\% by 2015, when it exhibited extensive areas of relic

133 Acropora skeletons (Fig. 1C) and a predominance of erect macroalgae ( $>60 \%$ cover) (Morillo-

134 Velarde et al., 2018). Based on a number of broad- and local-scale resilience indicators,

135 including coral cover, Ladd \& Collado-Vides (2013) categorized Limones as a high-resilience

136 site and Bonanza as a low-resilience site, whereas based on two different reef health indices,

137 Díaz-Pérez et al. (2016) categorized the health of Bonanza as "poor". Fishing activities are

138 banned on both Limones and Bonanza reefs since 1996. However, Bonanza is open to visitation,

139 whereas tourist activities are not allowed in Limones since 2014 given the high ecological value 
140

141

142

143

144

145

146

147

148

149

150

151

152

153

154

155

156

157

158

159

160

161

162

163

164

165

166

167

168

169

170

of this reef (Rodríguez-Martínez et al., 2014).

\section{Macrocrustacean surveys}

Sampling by divers remains the most efficient way to find reef-associated species when they are large enough to be seen (Knowlton et al., 2010; Giraldes, Coelho Filho \& Coelho, 2012). Therefore, we used SCUBA diving to conduct quantitative surveys of conspicuous macrocrustaceans (herein defined as motile crustaceans larger than $\sim 1 \mathrm{~cm}$ ) via belt transects, with a permit issued by Comisión Nacional de Acuacultura y Pesca (PPF/DGOPA-259/14). All underwater samplings were conducted by two scientific observers, who were thoroughly trained in macrocrustacean identification over several months prior to the samplings. Training was achieved by repeatedly studying an extensive guide of local crustacean species created in our lab with photos from many different sources, followed by direct identification in the field during several preliminary dives. In all cases, the results were cross-checked between both divers (Lessios, 1996; Backus, 2007). On each reef, we haphazardly laid thirty 25-m transects on the back reef zone along the length of the reef. The two divers recorded all macrocrustaceans observed within $1 \mathrm{~m}$ to the right and $1 \mathrm{~m}$ to the left of the transect line (i.e., an area of $50 \mathrm{~m}^{2}$ per transect), both over the substrata and under coral rubble. Individuals were identified in situ to the lowest possible taxonomic level and many were extensively photographed underwater to further help in their identification. Only a few individuals were collected in zip-lock bags and taken to the laboratory for their identification. Also recorded was the type of microhabitat in which each specimen was observed. These microhabitats included Acropora palmata, Agaricia agaricites, other live corals, Millepora spp., dead coral skeletons, coral rubble, gorgonians, algae, anemones, and sand. Despite their relatively large size, many macrocrustaceans hide deeply in holes and crevices in coral reefs during the day but forage over the reef substrata at night; therefore, to obtain a species list as complete as possible, we further conducted qualitative surveys on each reef by recording all species observed during three separate nocturnal 1-h dives.

\section{Structural complexity and benthic community}

We assessed the current ecological condition of the back-reef zones of Limones and Bonanza by using two metrics of structural complexity and estimating the percent cover of different components of the benthic community. Structural complexity was assessed with the 
171 Habitat Assessment Score (HAS; Gratwicke \& Speight, 2005), which is a qualitative metric, and

172 the rugosity index, which is a quantitative metric (Risk, 1972; Álvarez-Filip et al., 2009). HAS

173 provides an overall structural complexity value by visually evaluating six variables of the local

174 topography (rugosity, variety of growth forms, height, refuge size categories, percentage of live

175 cover, and percentage of hard substratum). Each variable is assigned a score between 1 and 5

176 (from smallest or lowest to largest or highest), and the sum of the individual scores is the HAS.

177 Therefore, a score of 6 would represent the least complex habitats and a score of 30 would

178 represent the most complex habitats. HAS values were obtained in three $4 \mathrm{~m}^{2}$ quadrats positioned 179 at the beginning, middle, and end of nine of 25-m transects per reef, and the three values were 180 averaged to obtain the transect-level HAS.

181 Rugosity is the ratio of the length of a chain molded to the reef surface to the linear 182 distance between its start and end points. A perfectly flat surface would have a rugosity index of 183 one, with larger numbers indicating more complex surfaces (Risk, 1972). To measure rugosity, a 184 chain ( $0.5 \mathrm{~cm}$ link-length) was molded to the reef surface along $2410-\mathrm{m}$ long transects on 185 Limones and 21 on Bonanza. These 10-m transects were also used to estimate percent cover of 186 components of the benthic community via the point intercept method (Hill \& Wilkinson, 2004).

187 The transects were marked every $10 \mathrm{~cm}$, thus yielding 100 points per transect (Lang et al., 2010), 188 A diver recorded which of the following benthic components was found under each mark: live 189 hard corals, calcareous macroalgae, fleshy macroalgae, coralline algae, algal turf, cyanobacterial 190 mat, other invertebrates (e.g. zoanthids, Millepora, Cliona), and other components (e.g. sand, 191 seagrass). component analysis (PCA). Then, the transformed data for each benthic component was compared between reefs with a Student's $t$-test.

\section{Characterization of the macrocrustacean community}


Quantifying biodiversity is problematic because there is no single "best" index. However,

203

204

205

206

207

208

209

210

211

212

213

214

215

216

217

218

219

220

221

222

223

224

225

226

227

228

229

230

simple indices (i.e., those that measure species richness) can be slightly preferable when the primary goal is to detect effects of external factors on diversity, whereas compound indices (i.e., those that combine measures of richness and abundance) can be preferable when the primary goal is to differentiate sites by their level of diversity (Magurran \& Dornelas, 2010; Morris et al., 2014). Given the aims of the present study, we estimated both types of indices for the macrocrustaceans from each reef. These indices included species richness ( $S$, number of species), Simpson's dominance $\left(D=\sum\left(n_{i} / \mathrm{N}\right)^{2}\right.$, where $n_{i}$ is number of individuals of the $i$ th species and $\mathrm{N}$

is total number of individuals), Shannon-Wiener's diversity $\left(H^{\prime}=-\sum_{i=1}^{s} p_{i} \log _{2} p_{i}\right.$, where $H^{\prime}$ is the information contained in the sample (bits/individual) and $\left.\mathrm{p}_{\mathrm{i}}=n_{i} / \mathrm{N}\right)$, and Pielou's evenness $\left(J^{\prime}=\right.$ $H^{\prime} / \log S$ ). Each index was compared between reefs with a Mann-Whitney U test. Species accumulation and rarefaction curves were computed using EstimateS v9.1.0 (Gotelli \& Colwell, 2001).

The community composition of macrocrustaceans was analyzed using multivariate techniques with PRIMER 6 v6.1.9 (PRIMER-E Ltd). Differences in the taxonomic composition between Limones and Bonanza were analyzed by non-metric multidimensional scaling (MDS) on fourth-root transformed data, using the Bray-Curtis similarity measure (Clarke, 1993). The statistical significance of the observed differences in the macrocrustacean assemblages between reefs was further tested with a one-way analysis of similarity (ANOSIM). This test provides an $\mathrm{R}$-value indicative of the degree of difference between samples as well as a p-value for the significance of that difference. $R$ values close to 0 are indicative of little difference while values close to 1 are indicative of a large difference in sample composition (Clarke \& Warwick, 2001). Finally, we did a similarity percentage analysis (SIMPER, Clarke, 1993) to identify those species responsible for the observed differences in community composition between both reefs. For each of the 10 most abundant species, we also compared the density, standardized as individuals (ind.) $50 \mathrm{~m}^{-2}$, between reefs with individual Student's $t$ tests.

\section{RESULTS}

\section{Structural complexity and benthic community components}


232 [interquartile range]) and Bonanza (1.24 [1.07-1.38]) did not differ significantly (Mann-Whitney

$233 \mathrm{U}$ test, $\mathrm{U}=182, \mathrm{z}=1.764, \mathrm{n}_{1}=25, \mathrm{n}_{2}=21, \mathrm{p}=0.078$ ) (Fig 2A). A similar result was obtained

234 for the median HAS (Fig. 2B) (Limones: 18 [16-20], Bonanza: 19 [17-19]; Mann-Whitney U

235 test, $\left.\mathrm{U}=38.5, \mathrm{z}=0.133, \mathrm{n}_{1}=\mathrm{n}_{2}=9, \mathrm{p}=0.895\right)$. However, the range in values of both metrics, in

236 particular rugosity (Fig. 2A), was substantially broader for Limones (1.05-3.56) than for

237 Bonanza (1.02-2.2), with rugosity values $\geq 2$ obtained on $32 \%$ transects on Limones versus $9.5 \%$

238 transects on Bonanza. The percent cover of various components of the benthic community

239 differed between reefs (Fig. 3). In particular, live coral cover was much higher on Limones,

240 whereas the cover of fleshy macroalgae, calcareous macroalgae, and cyanobacterial mats was

241 significantly higher on Bonanza (Fig. 3). In the PCA, the first two components explained $63 \%$ of

242 the total variance (Fig. 4). The first component explained $40.2 \%$ of the variance and was

243 positively correlated with fleshy macroalgae (loading: 0.640) and negatively correlated with live

244 hard coral (-0.685). The second component explained $22.8 \%$ of the variance and was strongly

245 positively correlated with turf algae (0.728) and negatively correlated with live hard coral (-

246 0.449) (Fig. 4). Most transects on Limones differed from those on Bonanza along the first

247 component.

The macrocrustacean assemblage

In all, we registered 63 species of macrocrustaceans (Table 1), including six that were only observed during the nocturnal dives (i.e., not quantified). These species were representatives of the Infraorders Brachyura (33 species), Caridea (10), Anomura (10), Achelata (5), Axiidea (2), and Stenopodidea (1); the Superfamily Penaeoidea (1), and the stomatopod family Gonodactyloidea ( 2 species). Twelve species, mostly rare (i.e., with $<3$ individuals), could only be identified to the superfamily or family level. The most diverse superfamily was Majoidea, with 22 species. The number of species was higher on Bonanza than on Limones (43 vs 33 species), as was the abundance (2800 vs 2067 individuals) (Table 1).

On both reefs, the number of species increased with the number of transects (accumulation curves, Fig. 5), but more steeply on Bonanza than on Limones. Rarefaction curves did not reach an asymptote for either reef, suggesting that the species richness of conspicuous macrocrustaceans on these reefs is even higher. All ecological indices differed significantly 
262 between reefs (Table 2), with Bonanza exhibiting higher levels of species richness ( $S$, Mann-

263 Whitney $\mathrm{U}$ test, $\left.\mathrm{U}=265.5, \mathrm{z}=-2.741, \mathrm{n}_{1}=\mathrm{n}_{2}=30, \mathrm{p}=0.004\right)$, diversity $\left(H^{\prime}, \mathrm{U}=208, \mathrm{z}=-3.57\right.$,

$\left.264 \mathrm{n}_{1}=\mathrm{n}_{2}=30, \mathrm{p}=0.0002\right)$, and evenness $\left(J^{\prime}, \mathrm{U}=261, \mathrm{z}=-2.787, \mathrm{n}_{1}=\mathrm{n}_{2}=30, \mathrm{p}=0.003\right)$,

265 whereas dominance was higher at Limones $\left(D, \mathrm{U}=176, \mathrm{z}=-4.044, \mathrm{n}_{1}=\mathrm{n}_{2}=30, \mathrm{p}<0.0001\right)$.

266 Macrocrustacean assemblages differed significantly between reefs (ANOSIM, $\mathrm{R}=0.279$,

$267 \mathrm{p}<0.001$ ) but with some overlap (Fig. 6), suggesting a similar abundance of some species on

268 both reefs. Indeed, SIMPER revealed that the clinging crab Mithraculus coryphe and the hermit

269 crab Calcinus tibicen were the most abundant species on both reefs, accounting for $71.4 \%$ and

$27062.2 \%$ of the similarities observed in Limones and Bonanza, respectively (Table 3). Within

271 Limones, the composition of macrocrustaceans exhibited an average similarity among transects

272 of $48.1 \%$, mainly due to three species: C. tibicen, M. coryphe and Domecia acanthophora, with

273 C. tibicen as the major contributor (45.2\%). Within Bonanza, the average similarity among

274 transects was $46.9 \%$, with $M$. coryphe emerging as the main contributor (33.1\%), followed by $C$.

275 tibicen (29.1\%) and Neogonodactylus oerstedii (8.8\%). On Limones, six species accounted for

$27690 \%$ of the observed similarity, whereas on Bonanza, this same percentage was accounted for by

277 eight species (Table 3). The crustacean assemblages of Limones and Bonanza exhibited a mean

278 dissimilarity of $58.5 \%$, with $D$. acanthophora as the main contributor to this dissimilarity $(8.1 \%)$,

279 followed by M. coryphe (6.6\%) and Pagurus brevidactylus (6.4\%).

280 Despite wide variability among transects, the density of some of the most abundant

281 species differed significantly between reefs (Fig. 7). This was the case for D. acanthophora,

282 which had a significantly higher density on Limones $\left(12.6 \pm 7.8\right.$ ind. $50 \mathrm{~m}^{-2}$, mean $\pm 95 \%$ CI,

283 than on Bonanza (1.5 \pm 1.9 ind. $\left.50 \mathrm{~m}^{-2}\right)$, and for $M$. coryphe, which exhibited a higher density on

284 Bonanza $\left(33.9 \pm 14.4\right.$ ind. $\left.50 \mathrm{~m}^{-2}\right)$ than on Limones $\left(9.7 \pm 3.6\right.$ ind. $\left.50 \mathrm{~m}^{-2}\right)$, as was also the case

285 for M. sculptus and N. oerstedii (Fig. 7). In contrast, the density of C. tibicen did not differ

286 significantly between reefs (Limones: $38.1 \pm 10.2$ ind. $50 \mathrm{~m}^{-2}$; Bonanza: $33.4 \pm 10.1$ ind. $50 \mathrm{~m}^{-2}$ ).

287 Two of the most abundant species were recorded on Limones only (Petrolisthes galathinus,

288 Paguristes cadenati) and one was recorded on Bonanza only (Paguristes tortugae) (Fig. 7).

289

290

291

Microhabitats used by macrocrustaceans

292

On Limones, the types of microhabitats more commonly occupied by macrocrustaceans were, on descending order, Millepora spp., A. palmata, coral rubble, dead coral skeletons, and 
293 Agaricia agaricites, and on Bonanza, coral rubble, dead coral skeletons, macroalgae, $A$.

294 agaricites, and Millepora spp. (Fig. 8). Some of these microhabitats constitute components of the

295 benthic community and hence their percent cover was estimated. For example, the average

296 percent cover of A. palmata and Millepora spp. was higher on Limones (29\% and 3.6\%,

297 respectively) than on Bonanza (3.5\% and 1.9\%, respectively). In contrast, the percent cover of

298 fleshy and calcareous macroalgae was higher on Bonanza (32.1\% and 15.4\%, respectively) than

299 on Limones (19.7\% and 5.2\%, respectively). However, other types of microhabitat (e.g., coral

300 rubble, relic coral skeletons, sand) were not quantified because they are not components of the

301 benthic community.

302

303

\section{DISCUSSION}

Contrary to our expectations, Bonanza supported a more diverse and abundant

305

306

307

308

309

310

311

312

313

314

315

316

317

318

319

320

321

322

323

macrocrustacean community than Limones, although there were differences between reefs in the percent cover of distinct benthic community components and the types of microhabitats used by macrocrustaceans. Live coral cover (mostly Acropora palmata) was much greater on Limones than on Bonanza, whereas the opposite occurred for fleshy and calcareous macroalgae, and cyanobacterial mats. These results support previous studies concluding that Bonanza has sustained substantial degradation over the past few decades (Carriquiry et al., 2013; Ladd \& Collado-Vides, 2013; Díaz-Pérez et al., 2016; Morillo-Velarde et al., 2018), whereas Limones is an exceptional site in that it has maintained healthy populations of Acropora palmata (Rodríguez-Martínez et al., 2014). Previously, Morillo-Velarde et al. (2018) found a significant difference in rugosity between Limones and Bonanza, but these authors measured this variable in only eight transects over the central part of each reef, where development of A. palmata on Limones appears to be greater. In contrast, we did not find a significant difference in the median rugosity between the back-reef zones of these reefs, which could be partially explained by the presence of extensive areas of dead coral skeletons on Bonanza as opposed to the extensive stands of live A. palmata on Limones. Thus, although our study was conducted in only two reefs, our results are consistent with studies suggesting that live coral cover is not necessarily a key factor determining the level of structural complexity as long as the reef structure persists (Lindahl, Ohmann \& Schelten, 2001; Nelson, Kuempel \& Altieri, 2016), i.e., that the relic skeletons (i.e. those left behind after the coral tissue dies) and the structural diversity they create 
324 can be important factors determining the diversity and structure of invertebrate communities

325 (Idjadi \& Edmunds, 2006). However, the wider range in rugosity over Limones, especially of

326 values $>2$, reflects the patchy presence of more complex substrates interspersed with less rugose

327 substrates. In contrast, the narrower range of values over Bonanza, with few values $>2$, suggests

328 a lower heterogeneity in substrate rugosity.

329 Reef invertebrates are highly diverse but hard to sample; in particular, many crustaceans

330 hide deeply in reef crevices or under sediments during the day and only emerge at night to forage

331 (Glynn \& Enochs, 2011). Therefore, even for conspicuous taxa, visual census methods have

332 several limitations that may result in underestimation of individuals present and sampling error,

333 such as observer variability, characteristics of the target taxa (e.g. crypticity, escape responses),

334 and difficulties imposed by environmental factors (e.g. turbidity, waves, current) (Lessios, 1996;

335 Backus, 2007). Indeed, a few individuals could only be identified to the superfamily level

336 because they either swam away rapidly (i.e. carideans) or retreated deeply into crevices, or

337 because time or environmental restrictions limited further identification. In addition, because our

338 studied reefs are within a marine protected area, we refrained from collecting but a few

339 individuals for further identification in the laboratory. Despite these limitations, species richness

340 was high on both Limones and Bonanza, as previously reported for other Caribbean reef systems

341 (Reed et al., 1982; Martínez-Iglesias \& García-Raso, 1999; Briones-Fourzán \& Lozano-Álvarez,

342 2002). However, a more exhaustive sampling would undoubtedly increase the number of

343 macrocrustacean species recorded in these reefs (e.g. Alpheidae and Thalassinidae) as indicated

344 by the rarefaction curves (see Fig. 5).

345 Most of the species that we observed on both reefs were facultative coral-dwelling 346 crustaceans, i.e., species that are not considered to be fundamentally dependent upon abundant

347 live coral for their local persistence (Stella et al., 2011). Although there was some overlap in the 348 macrocrustacean community composition between reefs, most diversity indices were higher on

349 Bonanza except for the dominance index, which was higher on Limones. These results likely

350 reflect a greater heterogeneity of microhabitats on Bonanza, which is characterized by the 351 abundance of relic coral skeletons, coral rubble, and erect fleshy and calcareous macroalgae 352 (Morillo-Velarde et al., 2018; the present study), than on Limones, which is characterized by 353 extensive stands of $A$. palmata and short algal turf (Rodríguez-Martínez et al., 2014; the present 354 study). The latter would also explain why Domecia acanthophora, a small commensal crab of 
355 Acropora spp. (Patton, 1967), was the main contributor to the dissimilarity between reefs. This

356 species is considered an obligate coral-dwelling crab (Patton, 1967), i.e., a species having strong

357 reliance on live corals for food, habitat, and/or recruitment (Stella et al., 2011). On the other

358 hand, fleshy and calcareous macroalgae, which were more abundant on Bonanza, offer high

359 quality microhabitats to grazing species (Roff et al., 2013) such as majoid crabs of the genera

360 Mithraculus, Mithrax, Omalacantha, and Maguimithrax, which use their modified, spooned-

361 shaped chelae to feed on these algae (Coen, 1988; Stachowicz \& Hay, 1996; Butler \& Mojica,

362 2012). Consequently, majoids were among the most abundant macrocrustaceans on Bonanza,

363 particularly $M$. coryphe, which on this reef was often found in coral rubble overgrown by

364 macroalgae. In Caribbean seagrass habitats, M. sculptus outranked M. coryphe in abundance

365 (Carmona-Suárez, 2000), but similar to our results, M. coryphe was the most abundant crab on

366 coralline substrates around an eastern Caribbean island (García, Hernández \& Bolaños, 1998).

367 The diogenid Calcinus tibicen had a similar abundance as M. coryphe on Bonanza, but

368 was the dominant species on Limones. This small hermit crab, which is an omnivorous

369 detritivore (Hazlett, 1981), has also been reported as abundant on shallow coral reefs in Panama

370 (Abele, 1976), Cuba (Martínez-Iglesias \& García-Raso, 1999), the Virgin Islands (Brown \&

371 Edmunds, 2013), and Brazil (Giraldes, Coelho Filho \& Coelho, 2012). Brown \& Edmunds

372 (2013) discovered that C. tibicen can live commensally on hydrozoans of the genus Millepora

373 ("fire corals"). Fire corals were more abundant on Limones than on Bonanza, and many of the

374 individuals of $C$. tibicen that we observed were dwelling on Millepora colonies. However, the

375 overall abundance of fire corals was low and we also found C. tibicen on virtually all types of

376 microhabitats except for anemones and sand, consistent with Brown \& Edmunds' (2013)

377 conclusion that the association with fire corals is facultative for this crab. In particular, C. tibicen

378 was observed in high numbers on relic coral skeletons and coral rubble on both reefs, but

379 especially on Bonanza, where these types of microhabitats abounded.

380 Specialist species are more vulnerable to disturbances and hence would be expected to be

381 more profoundly affected by coral reef degradation (Munday, 2004; Álvarez-Filip et al., 2015).

382 Based on our results, it would appear that Domecia acanthophora would be more profoundly

383 affected if Limones underwent an increase in degradation. Indeed, D. acanthophora was far

384 more abundant on Limones, where its preferred microhabitat (A. palmata) abounded, but we also

385 found it on Millepora spp. colonies on both reefs, although proportionally more on Bonanza, 
386

387

388

389

390

391

392

393

394

395

396

397

398

399

400

401

402

403

404

405

406

407

408

409

410

411

412

413

414

415

416

suggesting that these small crabs can associate with other sessile invertebrates in the absence of acroporids. For example, Reed et al. (1982) recorded D. acanthophora in Oculina reefs. Interestingly, Head et al. (2015) found large numbers of obligate coral-dwelling crabs on dead coral colonies of Acropora and Pocillopora across five different atolls. These crabs appeared to be explicitly recruiting to or moving to dead coral hosts at certain stages in their life cycle, with no relationship with the abundance of live coral (Head et al., 2015).

Our results would appear to confirm that, rather than structural complexity, the variety of microhabitats (i.e., small-scale habitat structure, Dumas et al., 2013) is an important factor driving the diversity and abundance of reef-associated crustaceans (Abele, 1976; Head et al., 2015; Giraldes et al., 2017), as is the diversity of mutualistic relationships that these animals can establish with other taxa (e.g., Patton, 1994; Briones-Fourzán et al., 2012; Brown \& Edmunds, 2013). For example, A. palmata provides habitat for many species, but is very vulnerable to diseases (Aronson \& Precht, 2001; Stella et al., 2011). In Australia, coral colonies displaying a significant reduction in live tissue cover due to partial mortality exhibited an increase in the abundance and richness of small invertebrate species, suggesting that as coral cover is reduced, new microhabitats arise within the colony, allowing other species to occupy new niches (Stella, Jones \& Pratchett, 2010). Thus, dead A. palmata may become important for macrocrustaceans for which the relic coral skeletons and coral rubble are preferred microhabitats. Several studies have already highlighted the importance of dead corals and coral rubble as key microhabitats for reef-dwelling decapod crustaceans (e.g. Coles, 1980; Enochs, 2012; Kramer, Bellwood \& Bellwood, 2014; Head et al., 2015) and other small invertebrates (Nelson, Kuempel \& Altieri, 2016). In addition to providing refuge, relic skeletons and coral rubble are typically overgrown by macroalgae, increasing their microhabitat value for herbivorous species (Roff et al., 2013).

An increase in the abundance and availability of mobile invertebrates with reef degradation may have positive effects on food web productivity by delaying the loss of other reef components such as fish (Rogers, Blanchard \& Mumby, 2018), thus potentially giving more time to reef communities to adapt to the new, more unfavorable, conditions. This hypothesis could explain why Morillo-Velarde et al. (2018) found a very similar food chain length between Limones and Bonanza reefs despite their contrasting levels of structural and benthic integrity. However, this does not mean that reef-associated crustaceans will benefit from coral reef degradation over the long term, because degraded coral reefs continue to erode over time (Perry 
417 et al., 2012), eventually reducing the availability of microhabitats with increasing loss of

418 structure and ecosystem functionality (Prezlawski et al., 2008; Head et al., 2015; Lozano-Álvarez

419 et al., 2017), resulting in low productivity over the longer term (Rogers, Blanchard \& Mumby,

420 2018). Given the ongoing tendency to increase of coral reef degradation, future studies should

421 investigate the relative importance of different types of microhabitats at different scales and the

422 occurrence of mutualistic relationships for maintaining diversity and abundance of reef-

423 associated macrocrustaceans.

424

425 CONCLUSIONS

426 Structural complexity is an important factor driving the diversity and abundance of reef-

427 associated macrocrustaceans, but so is the variety of local microhabitats and mutualistic

428 relationships that these animals can establish with other taxa. We found a greater diversity and

429 abundance of macrocrustaceans in a more degraded coral reef (Bonanza) than in a reef

430 characterized by extensive stands of live Acropora palmata (Limones), but the latter exhibited a

431 higher level of dominance, reflecting the presence in high numbers of a few species that establish

432 mutualistic relationships with A. palmata and hydrozoans. On Bonanza, relic skeletons and coral

433 rubble were typically overgrown by macroalgae, thus offering refuge and food to herbivorous

434 macrocrustaceans. However, coral reef degradation continues to increase, making it necessary to

435 investigate the relative importance of different types of microhabitats at different scales and at

436 different levels of degradation for maintaining diversity and abundance of reef-associated

437 macrocrustaceans.

438

439 ACKNOWLEDGEMENTS

440 The authors wish to acknowledge the invaluable technical assistance provided by C Barradas-

441 Ortiz and F Negrete-Soto throughout the study. Additional assistance in field and/or laboratory

442 work was provided by PS Morillo-Velarde, A Espinosa-Magaña, R Martínez-Calderón, R

443 Candia-Zulbarán, R Muñoz de Cote-Hernández, L Cid-González, N Luviano-Aparicio, and CE

444 Davies. E Escalante-Mancera helped with the use of software. Comments by Darren Brown

445 improved an earlier draft of the manuscript.

446

447 REFERENCES 
448

449

450

451

452

453

454

455

456

457

458

459

460

461

462

463

464

465

466

467

468

469

470

471

472

473

474

475

476

477

478

Abele LG. 1976. Comparative species composition and relative abundance of decapod

$$
\text { crustaceans in marine habitats of Panama. Marine Biology 38:263-278. DOI }
$$$$
\text { 10.1007/BF00388939 }
$$

Álvarez-Filip L, Dulvy NC, Gill JA, Côté IM, Watkinson AR. 2009. Flattening of Caribbean

$$
\text { coral reefs: region-wide declines in architectural complexity. Proceedings of the Royal }
$$

Society B 276: 3019-3025. DOI 10.1098/rspb.2009.0339

Álvarez-Filip L, Paddack MJ, Collen B, Robertson DR, Côté IM. 2015. Simplification of

$$
\begin{aligned}
& \text { Caribbean reef-fish assemblages over decades of coral reef degradation. PLoS One } \\
& \text { 10(4):e0126004. DOI 10.1371/journal.pone.0126004 }
\end{aligned}
$$

Aronson RB, Precht WF. 2001. White-band disease and the changing face of Caribbean coral reefs. Hydrobiologia 460:25-38. DOI 10.1007/978-94-017-3284-0_2

Backus GJ. 2007. Quantitative analysis of marine biological communities. Hoboken, NJ: Wiley Interscience.

Becker JA, Grutter AS. 2004. Cleaner shrimp do clean. Coral Reefs 23:515-520. DOI 10.1007/s00338-004-0429-3

Briones-Fourzán P, Lozano-Álvarez E. 2002. Shallow-water benthic decapod crustaceans of Chankanaab Park, Cozumel Island, Mexico. In: Escobar-Briones E \& Álvarez F (eds.) Modern Approaches to the Study of Crustacea. Kluwer/Plenum, Nueva York, pp. 197-204. DOI 10.1007/978-1-4615-0761-1_31

Briones-Fourzán P, Pérez-Ortiz M, Negrete-Soto F, Barradas-Ortiz C, Lozano-Álvarez E. 2012. Ecological traits of Caribbean sea anemones and symbiotic crustaceans. Marine Ecology Progress Series 470:55-68. DOI 10.3354/meps10030

Brown D, Edmunds PJ. 2013. The hermit crab Calcinus tibicen lives commensally on Millepora spp. in St. John, United States Virgin Islands. Coral Reefs 32:127-135. DOI 10.1007/s00338012-0948-2

Bruno JF, Bertness MD. 2001. Habitat modification and facilitation in benthic marine communities. In Bertness MD, Gaines SD, Hay ME (eds.) Marine community ecology. Sunderland, MA: Sinauer, pp. 201-218.

Bruno JF, Precht WF, Vroom PS, Aronson RB. 2014. Coral reef baselines: How much macroalgae is natural? Marine Pollution Bulletin 80:24-29. DOI 10.1016/j.marpolbul.2014.01.010 
479

480

481

482

483

484

485

486

487

488

489

490

491

492

493

494

495

496

497

498

499

500

501

502

503

504

505

506

507

508

509

Butler MJ IV, Mojica AM. 2012. Herbivory by the Caribbean king crab on coral patch reefs. Marine Biology 159:2697-2706. DOI 10.1007/s00227-012-2027-1

Carmona-Suárez CA. 2000. Differences between Mithraculus spp. communities in exposed and shelters shallow-water Thalassia beds in Venezuela. In: von Vaupel Kelin JC, Schram FR, eds. The biodiversity crisis and Crustacea. Rotterdam: Balkema, 419-430.

Carriquiry JD, Barranco-Servín LM, Villaescusa JA, Camacho-Ibar VF, Reyes-Bonilla H. 2013. Conservation and sustainability of Mexican Caribbean coral reefs and the threats of a humaninduced phase-shift. In: Silvern S, Young S (Eds) Environmental Change and Sustainability. InTech, London, pp. 29-51. DOI 10.5772/54339

Clarke KR. 1993. Non-parametric multivariate analyses of changes in community structure. Australian Journal of Ecology 18:117-143. DOI 10.1111/j.1442-9993.1993.tb00438.x

Clarke KR, Warwick RM. 2001. Change in marine communities: an approach to statistical analysis and interpretation, 2nd edition. PRIMER-E: Plymouth.

Coen LD. 1988. Herbivory by Caribbean majid crabs: feeding ecology and plant susceptibility. Journal of Experimental Marine Biology and Ecology 122:257-276. DOI 10.1016/00220981(88)90127-X

Coker DJ, Wilson SK, Pratchett MS. 2014. Importance of live coral habitat for reef fishes. Reviews in Fish Biology and Fisheries 24:89-126. DOI 10.1007/s11160-013-9319-5

Coles SL. 1980. Species diversity of decapods associated with living and dead reef coral Pocillopora meandrina. Marine Ecology Progress Series 2:281-291. DOI 10.3354/meps002281

Díaz-Pérez L, Rodríguez-Zaragoza FA, Ortiz M, Cupul-Magaña AL, Carriquiry JD, Ríos-Jara E, Rodríguez-Troncoso AP, García-Rivas MC. 2016. Coral reef health indices versus the biological, ecological and functional diversity of fish and coral assemblages in the Caribbean Sea. PLoS One 11(8):e0161812. DOI 10.1371/journal.pone.0161812

Dumas P, Jiménez H, Peignon C, Wantiez L, Adjeroud M. 2013. Small-scale habitat structure modulates the effects of no-take marine reserves for coral reef macroinvertebrates. PLoS One 8(3): e58998. DOI 10.1371/journal.pone.0058998

Enochs IC. 2012. Motile cryptofauna associated with live and dead coral substrates: implications for coral mortality and framework erosion. Marine Biology 159:709-722. DOI 10.1007/s00227-011-1848-7 
510 Fabricius KE, De'ath G, Noonan S, Uthicke S. 2014. Ecological effects of ocean acidification

511 and habitat complexity on reef-associated macroinvertebrate communities. Proceedings of the

512 Royal Society B 281:20132497. DOI 10.1098/rspb.2013.2479

513 Gardner TA, Côté IM, Gill JA, Grant A, Watkinson AR. 2003. Long-term region-wide declines

514 in Caribbean corals. Science 301:958-960. DOI 10.1126/science.1086050

515 García L, Hernández G, Bolaños J. 1998. Anomura y Brachyura de Isla de Aves. Saber

516 (Venezuela) 10(2):26-31.

517 Garpe KC, Yahya SAS, Lindahl U, Öhman MC. 2006. Long-term effects of the 1998 coral

518 bleaching event on reef fish assemblages. Marine Ecology Progress Series 315:237-247. DOI

$519 \quad 10.3354 /$ meps 315237

520 Giraldes BW, Coelho Filho PA, Coelho PA. 2012. Composition and spatial distribution of

521 subtidal decapoda on the "Reef Coast", northeastern Brazil, evaluated through a low-impact

522 visual census technique. Nauplius 20:187-201. DOI 10.1590/S0104-64972012000200010

523 Giraldes BW, Coelho Filho PA, Smyth DM, Coelho PA. 2017. The nocturnal zonation of

524 decapods in the subtidal zone within the reef seascape - abiotic factors defining habitats.

525 ICES Journal of Marine Science 74:2180-2190. DOI 10.1093/icesjms/fsx055

526 Glynn PW, Enochs IC. 2011. Invertebrates and their roles in coral reef ecosystems. In: Dubinsky

527 Z, Stambler N, eds. Coral reefs: an ecosystem in transition. Dordrecht: Springer, 273-325.

528 DOI 10.1007/978-94-007-0114-4_18

529 Gotelli NJ, Colwell RK. 2001. Quantifying biodiversity: procedures and pitfalls in the

530 measurement and comparison of species richness. Ecology Letters 4:379-391.

531 Graham NAJ, Nash KL. 2013. The importance of structural complexity in coral reef ecosystems.

532 Coral Reefs 32: 315-326. DOI 10.1046/j.1461-0248.2001.00230.x

533 Graham NAJ, Chabanet P, Evans RD, Jennings S, Letourneur Y, MacNeil MA, McClanahan TR,

534 Öhman MC, Polunin NVC, Wilson SK. 2011. Extinction vulnerability of coral reef fishes.

535 Ecology Letters 14:341-348. DOI 10.1111/j.1461-0248.2011.01592.x

536 Gratwicke B, Speight MR. 2005. Effects of habitat complexity on Caribbean marine fish

537 assemblages. Marine Ecology Progress Series 292:301-310. DOI 10.3354/meps292301

538 Hazlett BA. 1981. The behavioral ecology of hermit crabs. Annual Review of Ecology and

539 Systematics 12:1-22. DOI 10.1146/annurev.es.12.110181.000245

540 Head CEI, Bonsall MB, Koldewey H, Pratchett MS, Speight M, Rogers AD. 2015. High 
541 prevalence of obligate coral-dwelling decapods on dead corals in the Chagos archipelago,

542 central Indian Ocean. Coral Reefs 34:905-915. DOI 10.1007/s00338-015-1307-X

543 Hill J, Wilkinson C. 2004. Methods for ecological monitoring of coral reefs. Townsville:

544 Australian Institute of Marine Science.

545 Hughes TP, Barnes ML, Bellwood DR, Cinner JE, Cumming GS, Jackson JBC, Kleypas J, van

546 de Leemput IA, Lough JM, Morrison TH, Palumbi SR, van Nes EH, Scheffer M. 2017. Coral

547 reefs in the Anthropocene. Nature 546:82-90. DOI 10.1038/nature22901

548 Idjadi JA, Edmunds PJ. 2006. Scleractinian corals as facilitators for other invertebrates on a 549 Caribbean reef. Marine Ecology Progress Series 319:117-127. DOI 10.3354/meps319117

550 Jackson JBC, Donovan M, Cramer K, Lam V. 2014. Status and Trends of Caribbean Coral 551 Reefs: 1970-2012. Gland, Switzerland: Global Coral Reef Monitoring Network, IUCN. DOI

$552 \quad 10.13140 / 2.1 .4868 .6726$

553 Jordán-Dahlgren E. 1993. Atlas de los arrecifes coralinos del Caribe mexicano. Chetumal:

554 Centro de Investigaciones de Quintana Roo.

555 Kerry JT, Bellwood DR. 2015. Do tabular corals constitute keystone structures for fishes on 556 coral reefs? Coral Reefs 34: 41-50. DOI 10.1007/s00338-014-1232-4

557 Knowlton N, Brainard RE, Fisher R, Moews M, Plaisance L, Caley MJ. 2010. Coral reef 558 biodiversity. In: McIntyre AD, ed. Life in the world's oceans. Chichester: Wiley-Blackwell, $559 \quad 65-77$.

560 Kramer MJ, Bellwood DR, Bellwood O. 2014. Benthic Crustacea on coral reefs: a quantitative 561 survey. Marine Ecology Progress Series 511:105-116. DOI 10.3354/meps10953

562 Ladd MC, Collado-Vides L. 2013. Practical applications of monitoring results to improve 563 managing for coral reef resilience: a case study in the Mexican Caribbean. Biodiversity 564 Conservation 22:1591-1608. DOI 10.1007/s10531-013-0493-5

565 Lang JC, Marks KW, Kramer PA, Kramer PR, Ginsburg RN. 2010. AGRRA protocols version 566 5.4. Atlantic and Gulf Rapid Reef Assessment, http//www.agrra.org/training-tools/ 567 Lessios HA. 1996. Methods for quantifying abundance of marine organisms. In: Lang MA, 568 Baldwin CC, eds. Methods and techniques of underwater research. Nahant, MA: American 569 Academy of Underwater Sciences, 149-157.

570 Lindahl U, Öhman MC, Schelten CK. 2001. The 1997/1998 mass mortality of corals: effects on 571 fish communities on a Tanzanian coral reef. Marine Pollution Bulletin 42:127-131. DOI 
572

573

574

575

576

577

578

579

580

581

582

583

584

585

586

587

588

589

590

591

592

593

594

595

596

597

598

599

600

601

602

$10.1016 / \mathrm{S} 0025-326 \mathrm{X}(00) 00167-3$

Lozano-Álvarez E, Luviano-Aparicio N, Negrete-Soto F, Barradas-Ortiz C, Aguíñiga-García S, Morillo-Velarde PS, Álvarez-Filip L, Briones-Fourzán P. 2017. Does reef architectural complexity influence resource availability for a large reef-dwelling invertebrate? Journal of Sea Research 128:84-91. DOI 10.1016/j.seares.2017.08.010

Magurran AE, Dornelas M. 2010. Biological diversity in a changing world. Philosophical Transactions of the Royal Society B 365:3593-3597. DOI 10.1098/rstb.2010.0296

Martínez-Iglesias JC, García-Raso JE. 1999. The crustacean decapod communities of three coral reefs from the southwestern Caribbean Sea of Cuba: species composition, abundance and structure of the communities. Bulletin of Marine Science 65:539-557.

McKeon CS, Moore JM. 2014. Species and size diversity in protective services offered by coral guard-crabs. PeerJ 2:e574. DOI 10.7717/peerj.574

Morillo-Velarde PS, Briones-Fourzán P, Álvarez-Filip L, Aguíñiga-García S, Sánchez-González A, Lozano-Álvarez E. 2018. Habitat degradation alters trophic pathways but not food chain length on shallow Caribbean coral reefs. Scientific Reports 8:4109. DOI 10.1038/s41598-01822463-X

Morris EK, Caruso T, Buscot F, Fischer M, Hancock C, Maier TS, Meiners T, Müller C, Obermaier E, Prati D, Socher SA, Sonnemann I, Wäschke N, Wubet T Wurst S, Rillig MC. 2014. Choosing and using diversity indices: insights for ecological applications from the German Biodiversity Exploratories. Ecology and Evolution 4:3514-3524. DOI $10.1002 /$ ece 3.1155

Munday PL. 2004. Habitat loss, resource specialization, and extinction on coral reefs. Global Change Biology 10:1642-1647. DOI 10.1111/j.1365-2486.2004.00839.x

Nelson HR, Kuempel CD, Altieri AH. 2016. The resilience of reef invertebrate biodiversity to coral mortality. Ecosphere 7(7), e1399. DOI 10.1002/ecs2.1399

Newman SP, Meesters EH, Dryden CS, Williams SM, Sanchez C, Mumby PJ, Polunin NVC. 2015. Reef flattening effects on total richness and species responses in the Caribbean. Journal of Animal Ecology 84:1678-1689. DOI 10.1111/1365-2656.12429

Patton WK. 1967. Studies on Domecia acanthophora, a commensal crab from Puerto Rico, with particular reference to modifications of the coral host and feeding habits. Biological Bulletin 132:56-67. DOI 10.2307/1539878 
603 Patton WK. 1994. Distribution and ecology of animals associating with branching corals 604 (Acropora spp.) from the Great Barrier Reef, Australia. Bulletin of Marine Science 55:193605211.

606 Perry CT, Edinger EN, Kench PS, Murphy GN, Smithers SG, Steneck RS, Mumby PJ. 2012.

607 Estimating rates of biologically driven coral reef framework production and erosion: a new 608 census based carbonate budget methodology and applications to the reefs of Bonaire. Coral 609 Reefs 31:853-868. DOI 10.1007/s00338-012-0901-4

610 Przeslawski R, Ahyong S, Byrne M, Worheide G, Hutchings P. 2008. Beyond corals and fish: 611 the effects of climate change on non-coral benthic invertebrates of tropical reefs. Global 612 Change Biology 14:2773-2795. DOI 10.1111/j.1365-2486.2008.01693.x

613 Randall JE. 1967. Food habits of reef fishes of the West Indies. Studies in Tropical 614 Oceanography 5:655-847.

615 Reed JK, Gore RH, Scotto LE, Wilson KA. 1982. Community composition, structure, areal and 616 trophic relationships of decapods associated with shallow- and deep-water Oculina varicosa 617 coral reefs. Bulletin of Marine Science 32:761-786.

618 Risk MJ. 1972. Fish diversity on a coral reef in the Virgin Islands. Atoll Research Bulletin 619 193:1-6.

620 Roberts CM, Ormond RFG. 1987. Habitat complexity and coral reef fish diversity and 621 abundance on Red Sea fringing reefs. Marine Ecology Progress Series 4:1-8. DOI $622 \quad 10.3354 /$ meps041001

623 Rodríguez-Martínez RE, Banaszak AT, McField MD, Beltrán-Torres AU, Álvarez-Filip L. 2014. 624 Assessment of Acropora palmata in the Mesoamerican Reef System. PLoS One 9(4):e96140. 625 DOI 10.1371/journal.pone.0096140

626 Roff G, Wabnitz CCC, Harborne AR, Mumby PJ. 2013. Macroalgal associations of motile 627 epifaunal invertebrate communities on coral reefs. Marine Ecology 34:409-419. DOI $628 \quad 10.1111 /$ maec. 12040

629 Rogers A, Blanchard JL, Mumby PJ. 2018. Fisheries productivity under progressive coral reef 630 degradation. Journal of Applied Ecology 55:1041-1049. DOI 10.1111/1365-2664.13051

631 Stachowicz JJ, Hay ME. 1996. Facultative mutualism between an herbivorous crab and a 632 coralline alga: advantages of eating noxious seaweeds. Oecologia 105:377-387. DOI $633 \quad 10.1007 / \mathrm{BF} 00328741$ 
634 Stella JS, Jones GP, Pratchett MS. 2010. Variation in the structure of epifaunal invertebrate 635 assemblages among coral hosts. Coral Reefs 29:957-973. DOI 10.1007/s00338-010-0648-8

636 Stella JS, Pratchett MS, Hutchings PA, Jones GP. 2011. Coral-associated invertebrates: diversity, 637 ecological importance and vulnerability to disturbance. Oceanography and Marine Biology 638 Annual Review 49:43-104.

639 Stewart HL, Holbrook SJ, Schmitt RJ, Brooks AJ. 2006. Symbiotic crabs maintain coral health 640 by clearing sediments. Coral Reefs 25:609-615. DOI 10.1007/s00338-006-0132-7

641 Suchley A, McField MD, Álvarez-Filip L. 2016. Rapidly increasing macroalgal cover not related 642 to herbivorous fishes on Mesoamerican reefs. PeerJ 4:e2084. DOI 10.7717/peerj.2084

643 Tews J, Brose U, Grimm V, Tielborger K, Wichmann MC, Schwager M, Jeltsch F. 2004. Animal 644 species diversity driven by habitat heterogeneity/diversity: the importance of keystone 645 structures. Journal of Biogeography 31:79-92. DOI 10.1046/j.0305-0270.2003.00994.x 646 Vytopil E, Willis BL. 2001. Epifaunal community structure in Acropora spp. (Scleractinia) on 647 the Great Barrier Reef: implications of coral morphology and habitat complexity. Coral Reefs 648 20:281-288. DOI 10.1007/s003380100172

649 Warton DI, Hui FKC. 2011. The arcsine is asinine: the analysis of proportions in ecology. 650 Ecology 92:3-10. DOI 10.1890/10-0340.1 


\section{FIGURE LEGENDS}

653 Figure 1. Study area.

654 (A) Location of the studied reef units, Limones (well-preserved) and Bonanza (degraded), at 655 Puerto Morelos, México, and photographs showing the current state of (B) Limones and (C) 656 Bonanza. (Photo credits B: Lorenzo Álvarez-Filip; C: Fernando Negrete-Soto).

Figure 2. Metrics of reef structural complexity. Box plots of (A) rugosity index and (B) habitat assessment score (HAS) on Limones (green boxes) and Bonanza reefs (blue boxes). The lower and higher boundaries of the box indicate the $25^{\text {th }}$ and $75^{\text {th }}$ percentiles, respectively. The horizontal line within the box marks the median. Whiskers (error bars) above and below the box indicate the $90^{\text {th }}$ and $10^{\text {th }}$ percentiles. Black dots denote outliers.

664

Figure 3. Percent cover of benthic community components.

666 Percent cover of different benthic community components over Limones reef (green columns)

667 and Bonanza reef (blue columns). Error bars are 95\% confidence intervals. Asterisks at the end of a component name denote significant differences between reefs $(\alpha=0.05)$.

Figure 4. Principal Components Analysis (PCA) of percent cover of benthic components. reefs, Limones (green dots) and Bonanza (blue dots). Each dot represents a transect. LHC: live hard coral, TA: turf algae, FMA: fleshy macroalgae, CMA: calcareous macroalgae; CCA: coralline algae, CYAN: cyanobacterial mats, OINV: other sessile invertebrates, Other: other components (sand, seagrass).

Figure 5. Species accumulation and rarefaction curves. macrocrustacean species recorded in Limones (green lines) and Bonanza (blue lines) reefs. Thirty belt transects, $50 \mathrm{~m}^{2}$ each, were sampled on each reef. Rarefaction curves for either reef do not reach an asymptote, indicating the existence of more species.

682

Figure 6. nMDS ordination. samples from Limones reef (green triangles and dashed lines) and Bonanza reef (blue circles and continuous lines), based on species abundances. Each symbol denotes a transect.

Figure 7. Density of macrocrustaceans per reef.

Figure 8. Types of microhabitats used by macrocrustaceans. 


\section{Figure 1}

Study area.

(A) Location of the studied reef units, Limones (well-preserved) and Bonanza (degraded), at Puerto Morelos, México, and photographs showing the current state of (B) Limones and (C) Bonanza (Photo credits B: Lorenzo Álvarez-Filip; C: Fernando Negrete-Soto). 

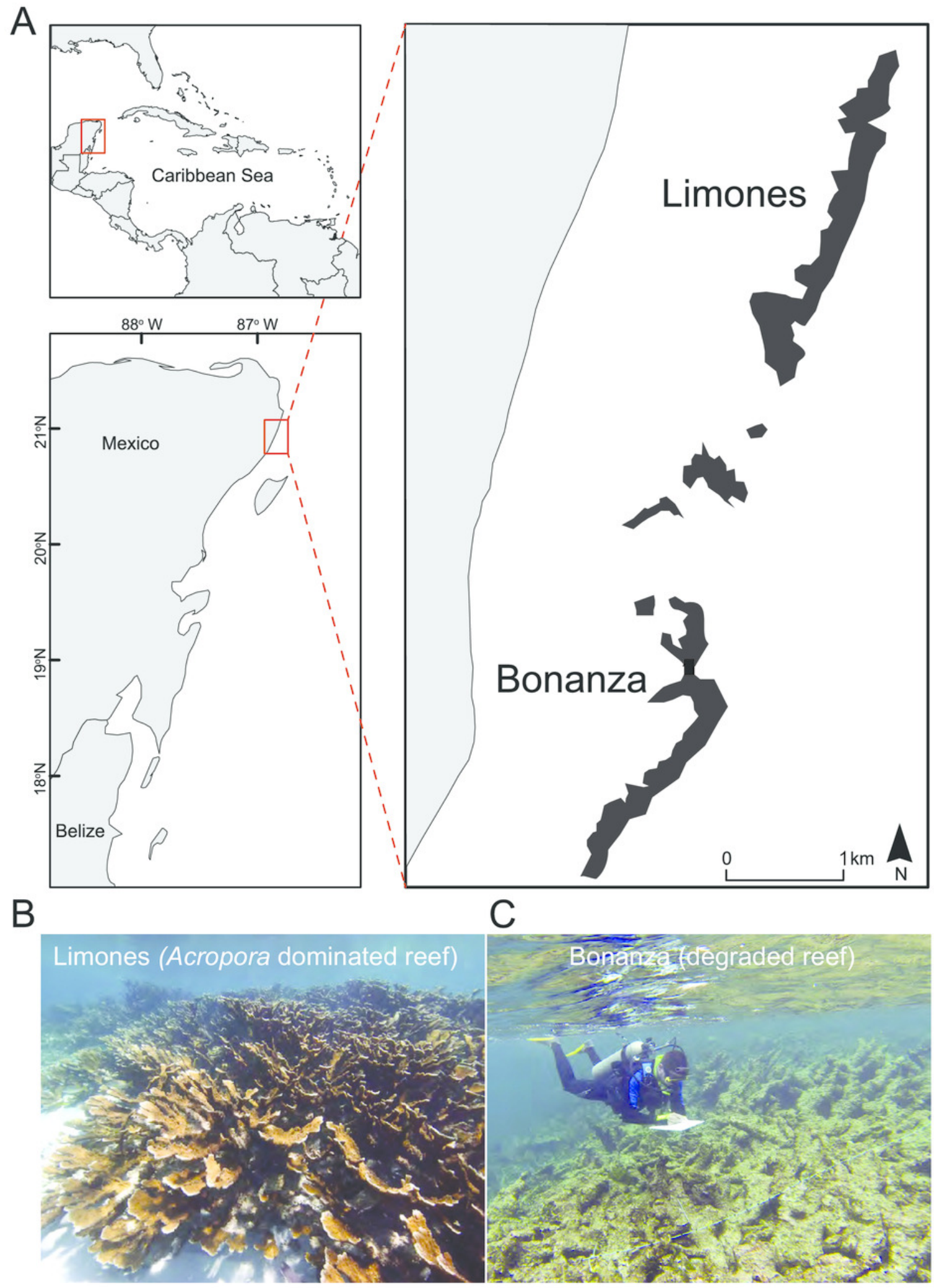
Figure 2

Metrics of reef structural complexity.

Box plots of (A) rugosity index and (B) habitat assessment score (HAS) on Limones (green boxes) and Bonanza reefs (blue boxes). The lower and higher boundaries of the box indicate the $25^{\text {th }}$ and $75^{\text {th }}$ percentiles, respectively. The horizontal line within the box marks the median. Whiskers (error bars) above and below the box indicate the $90^{\text {th }}$ and $10^{\text {th }}$ percentiles. Black dots denote outliers. 

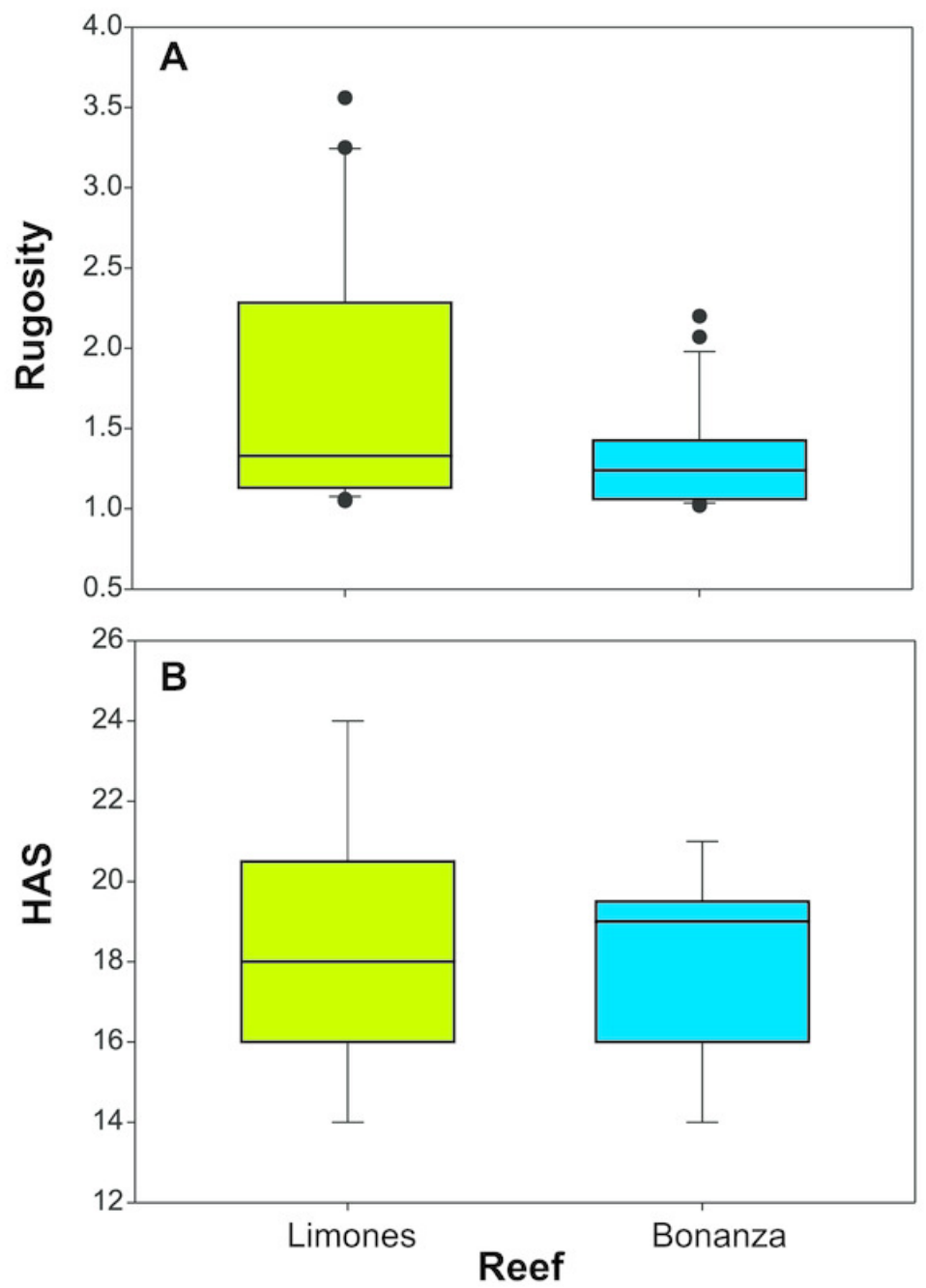


\section{Figure 3}

Percent cover of benthic community components.

Percent cover of different benthic community components over Limones reef (green columns) and Bonanza reef (blue columns). Error bars are 95\% confidence intervals. Asterisks at the end of a component name denote significant differences between reefs ( $\alpha=$ $0.05)$. 


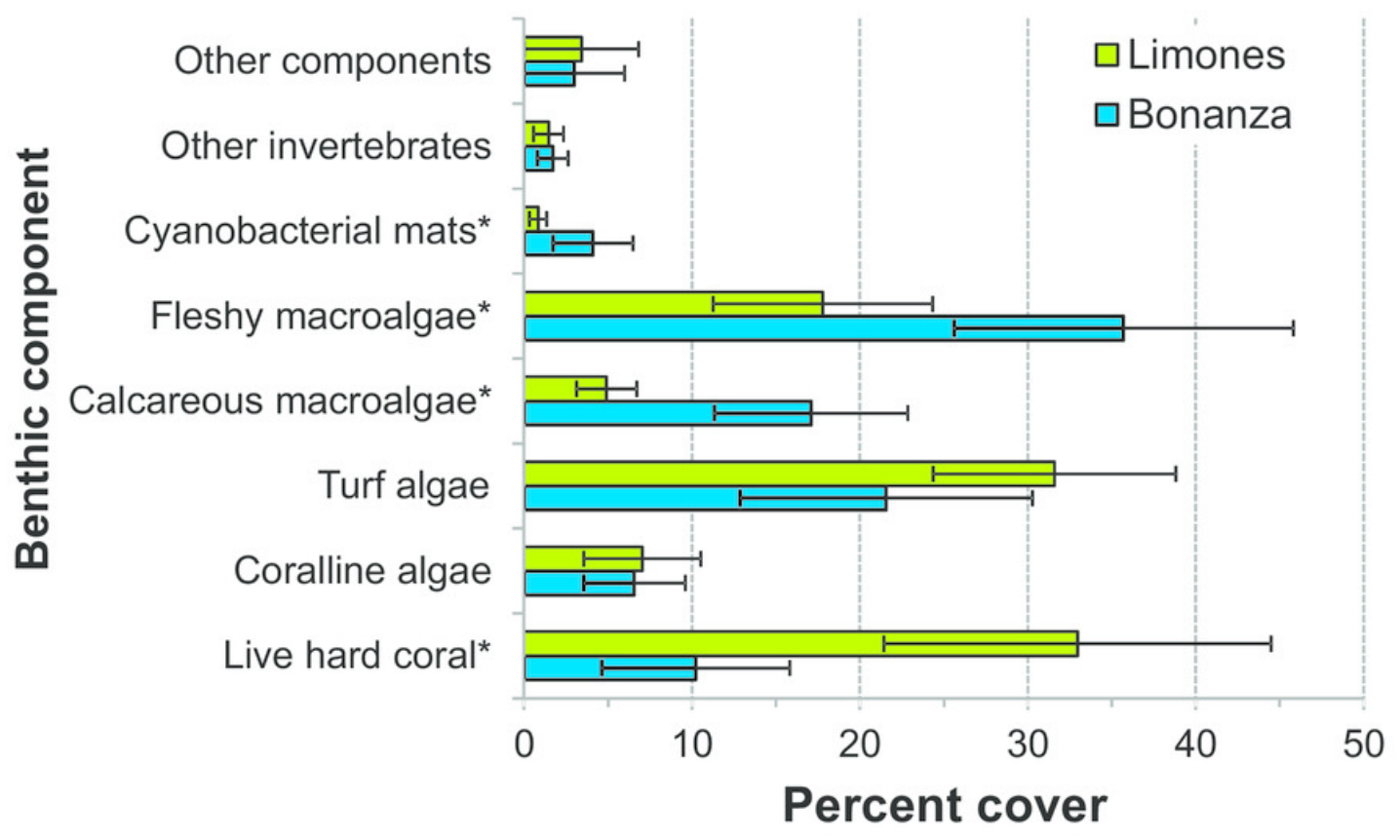




\section{Figure 4}

Principal Components Analysis (PCA) of percent cover of benthic components.

Bi-plot on logit-transformation of percent cover of benthic components over the two studied reefs, Limones (green dots) and Bonanza (blue dots). Each dot represents a transect. LHC: live hard coral, TA: turf algae, FMA: fleshy macroalgae, CMA: calcareous macroalgae; CCA: coralline algae, CYAN: cyanobacterial mats, OINV: other sessile invertebrates, Other: other components (sand, seagrass). 


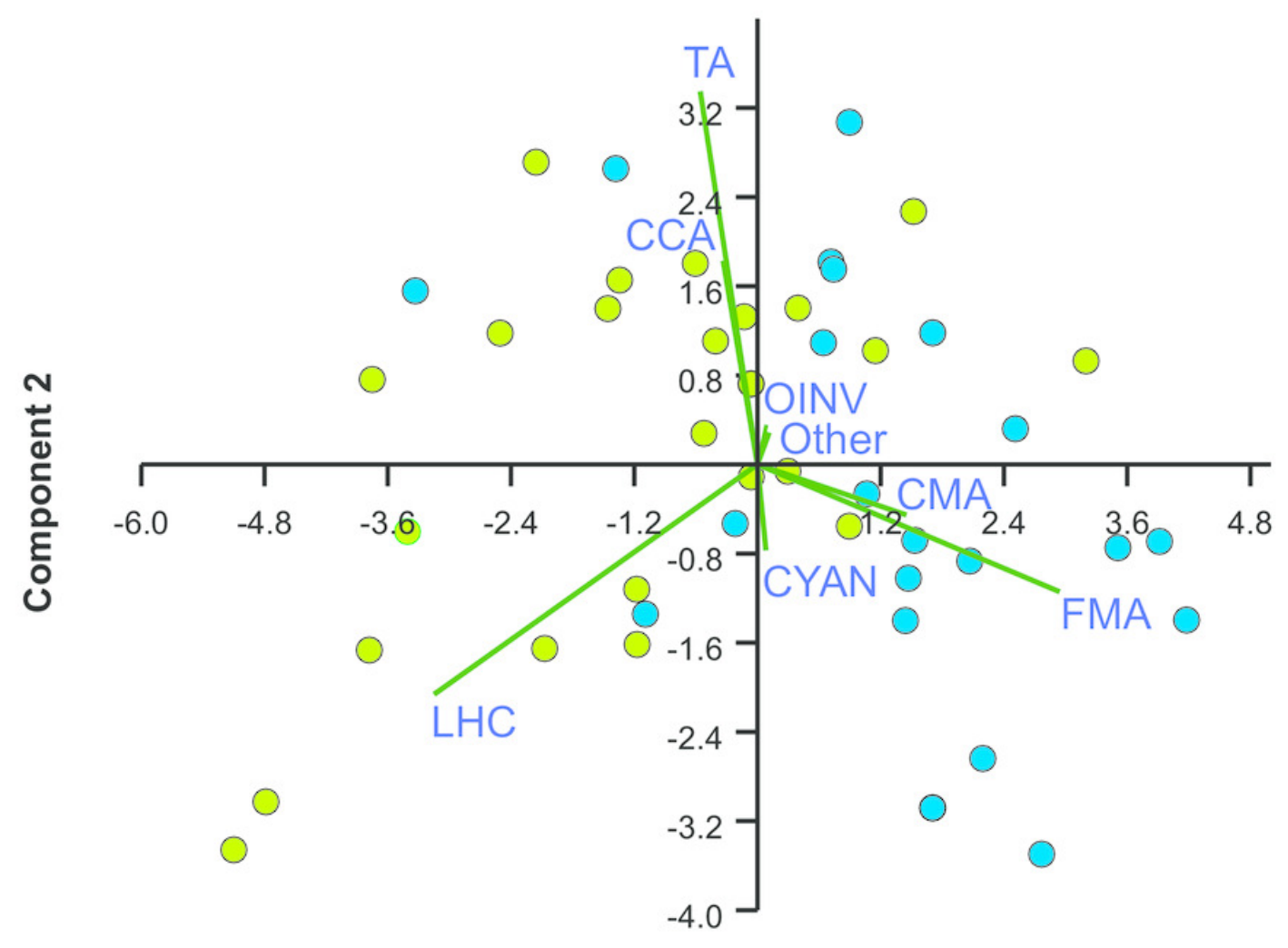

Component 1 


\section{Figure 5}

Species accumulation and rarefaction curves.

Accumulation curves (continuous lines) and rarefaction curves (dashed lines) for macrocrustacean species recorded in Limones (green lines) and Bonanza (blue lines) reefs. Thirty belt transects, $50 \mathrm{~m}^{2}$ each, were sampled on each reef. Rarefaction curves for either reef do not reach an asymptote, indicating the existence of more species. 


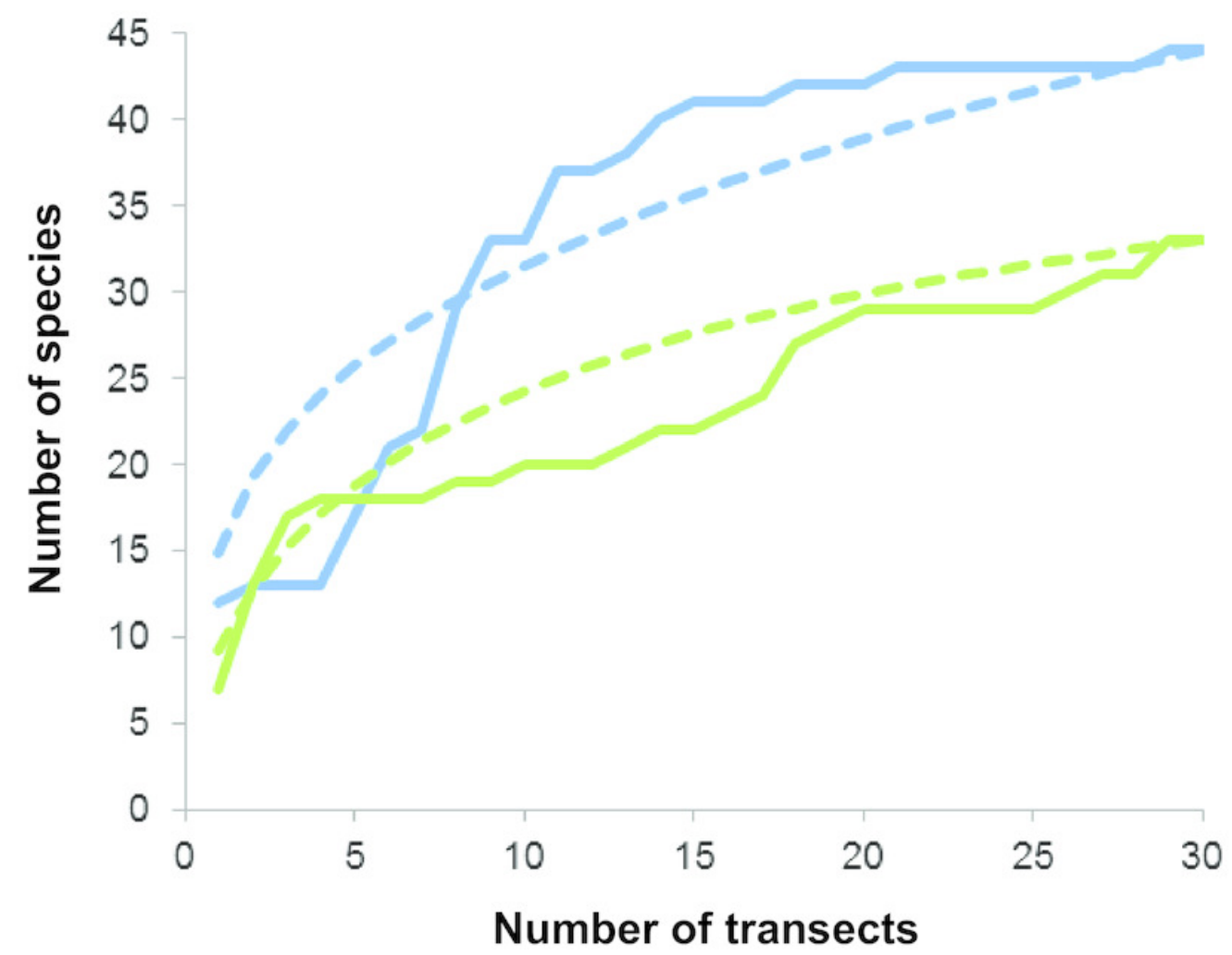


Figure 6

nMDS ordination.

Non-metric multidimensional (nMDS) ordination of macrocrustacean community structure in samples from Limones reef (green triangles and dashed lines) and Bonanza reef (blue circles and continuous lines), based on species abundances. Each symbol denotes a transect.

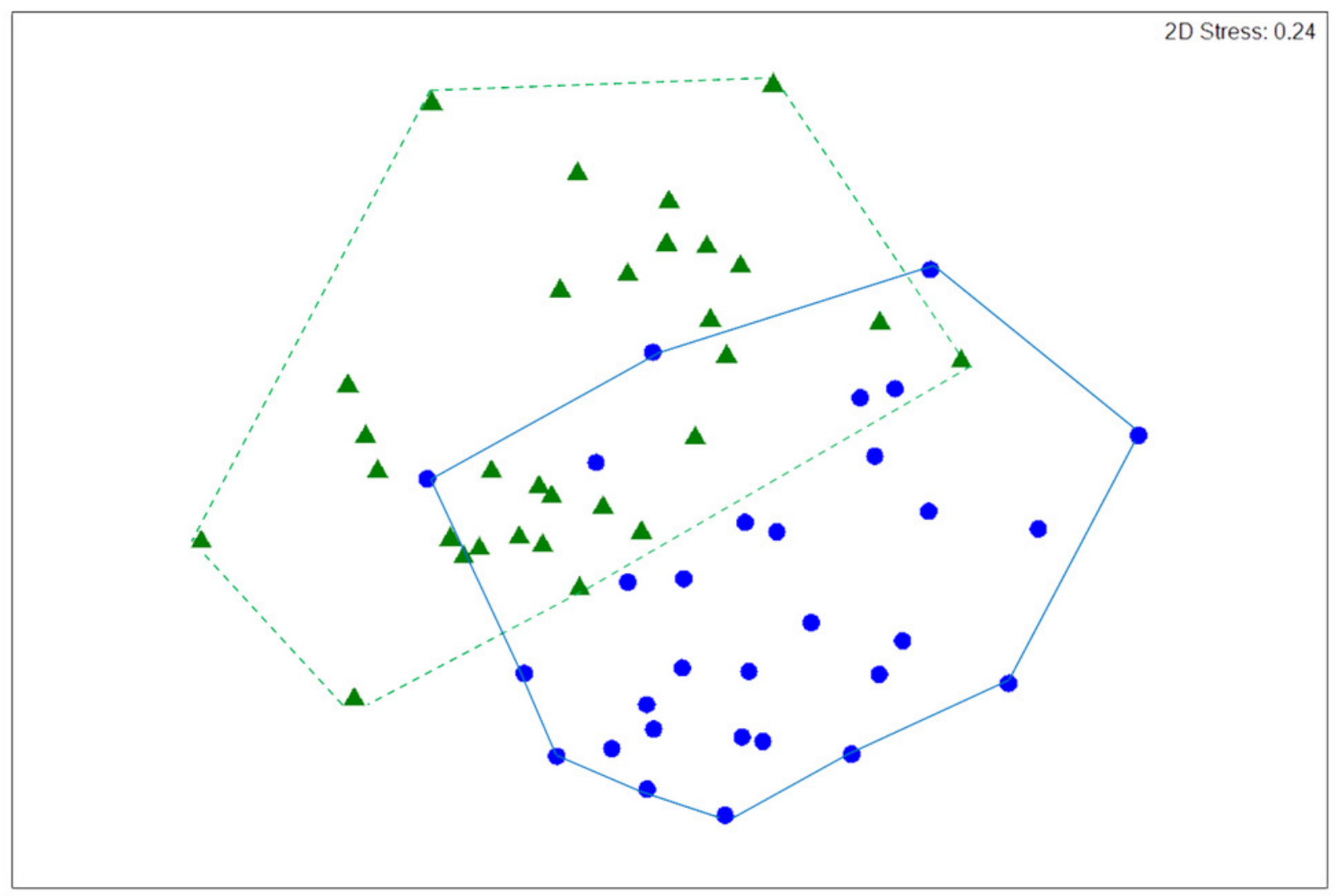




\section{Figure 7}

Density of macrocrustaceans per reef.

Mean density (number of individuals $50 \mathrm{~m}^{-2}$ ) of the most abundant macrocrustaceans per reef: Limones (green columns) and Bonanza (blue columns). Error bars are 95\% confidence intervals. 


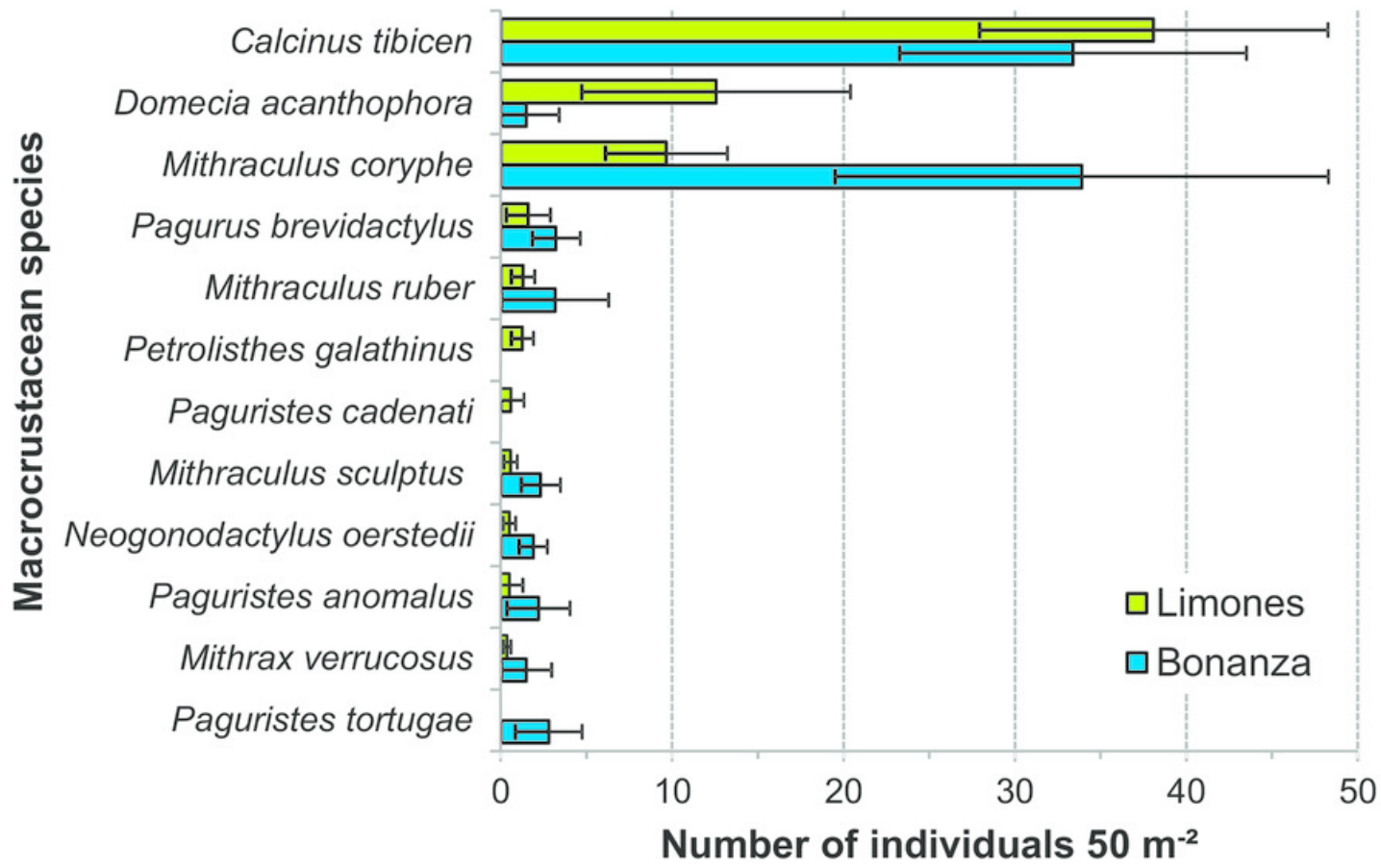


Figure 8

Types of microhabitats used by macrocrustaceans.

Comparison of the types of microhabitats used by macrocrustaceans on each reef, Limones (green columns) and Bonanza (blue columns). 


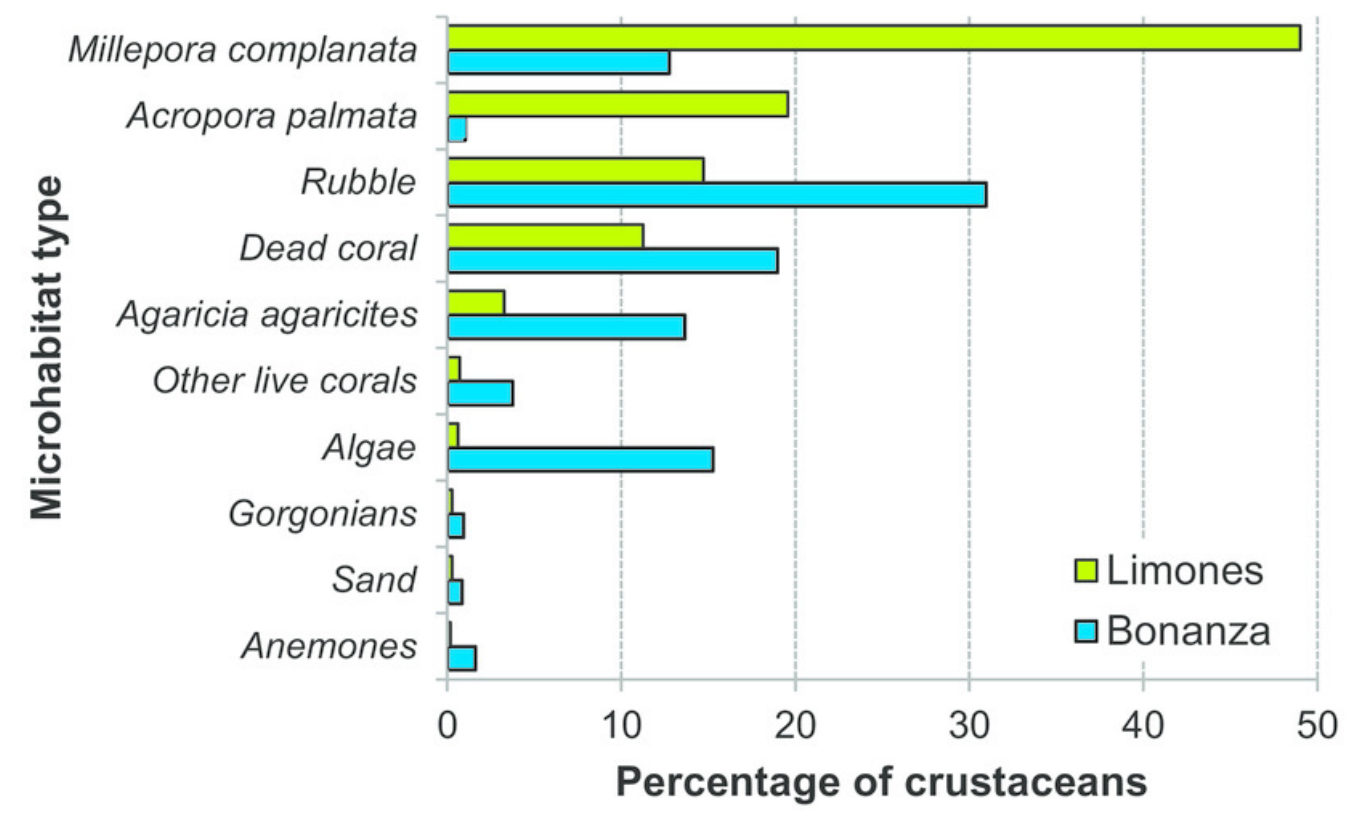




\section{Table $\mathbf{1}$ (on next page)}

Macrocrustacean species by reef.

Number of macrocrustacean species and individuals registered by visual census ( $\mathrm{n}=30$

transects). Bonanza reef: 43 species; 2800 individuals; Limones reef: 33 species; 2067 individuals. An $\mathrm{X}$ denotes that a species was only qualitatively recorded during nocturnal dives. 


\begin{tabular}{|c|c|c|c|}
\hline & Species & Bonanza & Limones \\
\hline 1 & Mithraculus coryphe (Herbst, 1801) & 1017 & 290 \\
\hline 2 & Calcinus tibicen (Herbst, 1791) & 1002 & 1143 \\
\hline 3 & Pagurus brevidactylus (Stimpson, 1859) & 97 & 48 \\
\hline 4 & Teleophrys ruber (Stimpson, 1871) & 95 & 40 \\
\hline 5 & Paguristes tortugae Schmitt, 1833 & 84 & 0 \\
\hline 6 & Mithraculus sculptus (Lamarck, 1818) & 70 & 17 \\
\hline 7 & Paguristes anomalus Bouvier, 1918 & 66 & 15 \\
\hline 8 & Neogonodactylus oerstedii (Hansen, 1895) & 57 & 15 \\
\hline 9 & $\begin{array}{l}\text { Domecia acanthophora (Desbonne in Desbonne \& } \\
\text { Schramm, 1867) }\end{array}$ & 45 & 377 \\
\hline 10 & Mithrax aculeatus (Herbst, 1790) & 45 & 11 \\
\hline 11 & Omalacantha bicornuta (Latreille, 1825) & 43 & \\
\hline 12 & Alpheus armatus Rathbun, 1901 & 19 & 4 \\
\hline 13 & Paguristes puncticeps Benedict, 1901 & 19 & 4 \\
\hline 14 & Callianassid A & 19 & 1 \\
\hline 15 & Thor amboinensis (de Man, 1888) & 19 & 0 \\
\hline 16 & Panulirus argus (Latreille, 1804) & 18 & 4 \\
\hline 17 & Macrocoeloma subparellelum (Stimpson, 1860) & 14 & 0 \\
\hline 18 & Axiopsis serratifrons (A. Milne-Edwards, 1873) & 12 & 4 \\
\hline 19 & Percnon gibbesi (H. Milne-Edwards, 1853) & 8 & 7 \\
\hline 20 & Nonala holderi (Stimpson, 1871) & 7 & 0 \\
\hline 21 & Petrolisthes galathinus (Bosc, 1802) & 5 & 38 \\
\hline 22 & Macrocoeloma diplacanthum (Stimpson, 1860) & 5 & 0 \\
\hline 23 & Xanthid E & 4 & 0 \\
\hline 24 & Mithraculus cinctimanus Stimspon, 1860 & 3 & 3 \\
\hline 25 & Stenopus hispidus (Olivier, 1811) & 3 & 0 \\
\hline 26 & Actaea acantha (H. Milne-Edwards, 1834) & 2 & 0 \\
\hline 27 & Ancylomenes pedersoni (Chace, 1958) & 2 & 0 \\
\hline 28 & Ratha longimanus (H. Milne-Edwards, 1834) & 2 & 0 \\
\hline 29 & Macrocoeloma trispinosum (Latreille, 1825) & 2 & 0 \\
\hline 30 & Mithraculus forceps A. Milne-Edwards, 1875 & 2 & 0 \\
\hline 31 & Panulirus guttatus (Latreille, 1804) & 1 & 3 \\
\hline 32 & Lysmata wurdemanni (Gibbes, 1850) & 1 & 1 \\
\hline 33 & Anomuran A & 1 & 0 \\
\hline 34 & Brachycarpus biunguiculatus (Lucas, 1846) & 1 & 0 \\
\hline 35 & Majoid B & 1 & 0 \\
\hline 36 & Majoid C & 1 & 0 \\
\hline 37 & Majoid D & 1 & 0 \\
\hline 38 & Neogonodactylus torus (Manning, 1869) & 1 & 0 \\
\hline
\end{tabular}


39 Pitho lherminieri (Desbonne in Desbonne \& $\quad 1 \quad 0$ Schramm, 1867)

40 Pitho mirabilis (Herbst, 1794) $\quad 1 \quad 0$

41 Podochela macrodera Stimpson, $1860 \quad 1 \quad 0$

42 Stenorhynchus seticornis (Herbst, 1788) $\quad 1 \quad 0$

43 Xanthid C 110

44 Xanthid D $\quad 1 \quad 0$

45 Paguristes cadenati Forest, $1954 \quad 0018$

46 Phimochirus holthuisi (Provenzano, 1961) 00

47 Caridean A $\quad 0 \quad 3$

48 Pachycheles pilosus (H. Milne Edwards, 1837) $\quad 0 \quad 3$

49 Cinetorhynchus manningi (Okuno, 1996) 002

50 Majoid A $\quad 0 \quad 2$

51 Nemausa acuticornis (Stimpson, 1871) $\quad 0 \quad 2$

52 Damithrax hispidus (Herbst, 1790) $\quad 0 \quad 1$

53 Maguimithrax spinosissimus (Lamarck, 1818) $\quad 0 \quad 1$

54 Achelous sebae (H. Milne Edwards, 1834) $\quad 0 \quad 1$

55 Synalpheus sp. $\quad 0 \quad 1$

56 Xanthid A $\quad 0 \quad 1$

57 Xanthid B $\quad 0 \quad 1$

58 Cinetorhynchus rigens (Gordon, 1936) $\quad \mathrm{X} \quad \mathrm{X}$

59 Metapenaeopsis goodei (Smith, 1885) X X X

60 Palinurellus gundlachi von Martens, 1878 X

61 Parribacus antarcticus (Lund, 1793)

62 Scyllarides aequinoctialis (Lund, 1793) $\quad$ X $\quad$ X

63 Carpilius corallinus (Herbst, 1783) X 


\section{Table 2 (on next page)}

Ecological indices for macrocrustaceans by reef.

Mean value ( $\pm 95 \%$ confidence interval) of species richness (S), Shannon-Wiener diversity $\left(H^{\prime}\right)$, dominance $(D)$, and evenness $\left(J^{\prime}\right)$ of macrocrustaceans on Bonanza and Limones reefs. 
1

\section{Ecological Index Bonanza reef Limones reef}

2

$\begin{array}{lll}\text { S } & 8.66 \pm 1.18 & 6.53 \pm 0.71 \\ \text { H' } & 2.07 \pm 0.19 & 1.54 \pm 0.15 \\ \text { D } & 0.33 \pm 0.04 & 0.47 \pm 0.05 \\ \text { J } & 0.69 \pm 0.04 & 0.58 \pm 0.04\end{array}$

3 


\section{Table 3(on next page)}

Similarity measures within and between reefs.

Analysis of similarity percentage (SIMPER) for macrocrustacean assemblages within Limones and Bonanza, and of dissimilarity percentage between reefs. 
1

Limones. Average similarity: 48.10

\section{Species}

Calcinus tibicen

Mithraculus coryphe

Domecia acanthophora

Petrolisthes galathinus

Teleophrys ruber

Pagurus brevidactylus

Bonanza: Average similarity: 46.90

Mithraculus coryphe

Calcinus tibicen

Neogonodactylus oerstedii

Pagurus brevidactylus

Mithraculus sculptus

Omalacantha bicornuta

Paguristes tortugae

Teleophrys ruber

$\begin{array}{ccccc}\text { AA } & \text { AS } & \text { Sim/SD } & \text { Contrib\% } & \text { Cum \% } \\ 2.33 & 21.73 & 4.10 & 45.18 & 45.18 \\ 1.52 & 12.62 & 2.07 & 26.23 & 71.41 \\ 1.04 & 4.16 & 0.57 & 8.65 & 80.06 \\ 0.58 & 2.18 & 0.50 & 4.54 & 84.60 \\ 0.52 & 1.71 & 0.41 & 3.55 & 88.16 \\ 0.51 & 1.66 & 0.41 & 3.46 & 91.61\end{array}$

$\begin{array}{lcccc}2.22 & 15.54 & 3.64 & 33.14 & 33.14 \\ 2.15 & 13.64 & 2.51 & 29.09 & 62.22 \\ 0.85 & 4.12 & 0.89 & 8.79 & 71.02 \\ 0.90 & 3.40 & 0.77 & 7.25 & 78.27 \\ 0.76 & 2.85 & 0.64 & 6.08 & 84.35 \\ 0.52 & 1.29 & 0.45 & 2.75 & 87.10 \\ 0.57 & 1.07 & 0.37 & 2.29 & 89.39 \\ 0.52 & 0.80 & 0.33 & 1.70 & 91.09\end{array}$

Limones and Bonanza: Average dissimilarity: 58.49

\section{Species}

Domecia acanthophora

Mithraculus coryphe

Pagurus brevidactylus

Calcinus tibicen

Neogonodactylus oerstedii

Mithraculus sculptus

Teleophrys ruber

Petrolisthes galathinus

Paguristes tortugae
Limones Bonanza

$\begin{array}{cccccc}\text { AA } & \text { AA } & \text { AD } & \text { Dis/SD } & \text { Contrib\% } & \text { \% } \\ 1.04 & 0.29 & 4.76 & 0.96 & 8.14 & 8.14 \\ 1.52 & 2.22 & 3.88 & 1.23 & 6.63 & 14.77 \\ 0.51 & 0.90 & 3.73 & 1.17 & 6.38 & 21.15 \\ 2.33 & 2.15 & 3.55 & 0.99 & 6.07 & 27.22 \\ 0.33 & 0.85 & 3.43 & 1.21 & 5.86 & 33.08 \\ 0.34 & 0.76 & 3.39 & 1.07 & 5.80 & 38.88 \\ 0.52 & 0.52 & 3.10 & 0.97 & 5.30 & 44.18 \\ 0.58 & 0.11 & 2.61 & 0.90 & 4.46 & 48.64 \\ 0.00 & 0.57 & 2.28 & 0.72 & 3.90 & 52.54\end{array}$

AA
3.90

2 AA: average abundance; AS: average similarity; Sim/SD: similarity/standard deviation; Contrib

$3 \%$ : contribution in \%; Cum \%: cumulative contribution in \%; AD: average dissimilarity; Dis/SD:

4 dissimilarity/standard deviation). Species are listed in decreasing order of AS within each reef

5 and $\mathrm{AD}$ between reefs. Cum.\% does not reach 100\% in order to facilitate interpretation.

6 